\title{
Joanna Flis
}

Uniwersytet Szczeciński

E-MAIL: psychoterapiaflis@gmail.com

\section{Maszyny samouczące się - wyzwanie współczesnej pedagogiki}

\begin{abstract}
STRESZCZENIE
Artykuł podejmuje problematykę pedagogiki sztucznej inteligencji (AIP - artificial intelligence pedagogy) przybliżając jej znaczenie w kontekście problematyki związanej z big data i uczeniem maszynowym. Przedstawia zaproponowaną przez zespół J. Bieger, K.R. Thórisson i B.R. Steunebrink koncepcję pedagogicznego pentagonu, traktując jednocześnie propozycję pięciu podstawowych pojęć nowej teorii uczenia, zaproponowanych przez wymieniony zespół (uczniowie, środowisko zadaniowe, testowanie służące poznawaniu ucznia i jego postępów, szkolenie i nauczanie dotyczące ogólnej strategii, metod i narzędzi w AP - Artificial Pedagogy) jako punkt wyjścia do dyskusji o wprowadzeniu humanistycznego wymiaru do robotyki, czy rozwoju technologii sztucznej inteligencji. W tym celu wykorzystuje zaproponowaną przez A. Makowską i M. Chutorańskiego koncepcję pedagogiki rzeczy, ukazując jej potencjał wyjaśniający, jak i uwrażliwiający dla dalszego rozwoju pedagogiki sztucznej inteligencji.

SŁOWA KLUCZOWE: pedagogika sztucznej inteligencji, sztuczna inteligencja, pedagogika rzeczy, pedagogiczny pentagon, samouczenie się maszyn
\end{abstract}

\section{Wprowadzenie}

Poniższy artykuł ma na celu przybliżenie czytelnikowi nieobecnej jeszcze w polskiej literaturze koncepcji pedagogiki sztucznej inteligencji (AIP - artificial intelligence pedagogy). Akcentuję i rozważam w nim wartość wynikającą z włączenia się środowiska pedagogów do obszaru nauk o sztucznej inteligencji. Koncepcję samej AIP odnoszę do usytuowanej posthumanistycznie idei pedagogiki rzeczy (proponowanej przez Anetę Makowską i Maksymiliana Chutorańskiego), która w mojej opinii może proponować ciekawą perspektywę badawczą.

\section{Big Data}

„W ciągu ostatnich dwóch lat wyprodukowaliśmy więcej danych niż od początku istnienia ludzkości” (Forbes, 2017). To obrazuje problemy społeczeństwa informacyjnego, czyli takiego, w którym „rolę kluczową pełni sektor informacji” (Szwed, 2003, s. 8). Człowiek bowiem ma „ograniczenia 
biologiczne i możliwości odbioru określonej liczby informacji w procesie uczenia się" (Siemieniecki, 2013, s. 164), stąd między innymi jego nieprzerwane dążenie do stworzenia supermaszyny.

Do zjawiska zwanego informacyjnym potopem (Selwyn, 2015) przyczyniają się również różne praktyki organizacji procesów kształcenia, np. gromadzenie danych w dziennikach elektronicznych. Wszystkie gromadzone informacje z czasem mogą tworzyć zestaw kompleksowych danych na temat rozwoju i funkcjonowania członków określonych społeczności. Z powodzeniem - według zwolenników ich gromadzenia - mogą one zostać wykorzystane do ewaluacji i zwiększenia wydajności procesów kształcenia. Jakub Czopek przekonuje, iż „walory poznawcze, jakie Big Data oferuje, muszą zostać uznane za nową jakość w opisywaniu i diagnozowaniu działalności pojedynczej szkoły czy grupy placówek na danym obszarze. Jakość, która może zdecydowanie poprawić ich funkcjonowanie" (2017, s. 88). Jednak z równie dużym prawdopodobieństwem dane te mogą zwiększać moc dyskryminacyjną takich czynników, jak wątki biograficzne, miejsce zamieszkania czy przynależność do określonej grupy społecznej. Spełnienie postulatu usprawnienia funkcjonowania sztucznej inteligencji może pozwolić na ograniczenie wspomnianej wcześniej mocy dyskryminacyjnej stosowanych algorytmów. Algorytmy te, zwane Beemzetami, oparte są jednak jedynie na założeniach i przewidywaniach ich twórców, i - mimo swojej użyteczności - pomijają czynniki przez nich niedostrzegane. Przez to obarczone są szczególnym błędem wnioskowania, wynikającym z ich budowy, który ma potencjał dyskryminacyjny (O’Neil, 2017).

Zbudowanie supermaszyny, która usprawniłaby Big Data, czyli „wyciąganie wniosków z analizy olbrzymiej ilości danych dostępnych cyfrowo" (Czopek, 2017, s. 83), wymaga algorytmu, który będzie potrafił w krótkim czasie odszukać określone prawidłowości. Najszybszy komputer świata Summit posiada moc obliczeniową 200 biliardów kalkulacji na sekundę (nauka. us.edu.pl, 2018). Oznacza to, iż pojedynczemu człowiekowi powtórzenie sekundy jego pracy zajęłoby 6,36 miliarda lat. „Gdyby zaś każdy człowiek na Ziemi wykonywał pojedyncze obliczenie co sekundę, całej populacji zajęłoby 305 dni zrobienie tego, co Summit robi w jedną sekundę" (Rosenfield, 2018). Połączenie szybkości z możliwościami, jakie daje technologia sztucznej inteligencji może przybliżyć naukowców do stworzenia idealnej Sztucznej Ogólnej Inteligencji (AGI), czyli takiej, która przekroczy dotychczasowe ograniczenia sztucznej inteligencji (AI)․․ Część badaczy uważa, że uda się to osiągnąć do

1 Istnieje kilka typów sztucznej inteligencji. W tym artykule posługiwać się będę dwoma pojęciami: Sztucznej Inteligencji (AI) oraz (AGI), która „w zakresie możliwości poznaw- 
roku 2040 (Müller i Bostrom, 2014). Dla przykładu - tylko Komisja Europejska przeznaczy w latach 2021-2027 na program „Cyfrowa Europa” 9,2 mld EUR, z czego 2,5 mld na projekty związane z rozpowszechnianiem sztucznej inteligencji (Sztokfisz, 2018).

\section{Uczenie się maszyn}

Używane w tym artykule sformułowania „uczenie maszynowe” lub „maszyny samouczące się" zaczerpnięte są z nauki o AI. Maszyny takie wyposażone są w systemy uczące się, dzięki którym adaptują się i zmieniają swoje wewnętrzne parametry. Owe systemy nazywane są maszynowym uczeniem (ML: Machine Learning) (Stefanowski, 2009). Maszyna wyposażona w taki system „wykorzystuje zewnętrzne dane empiryczne w celu tworzenia i aktualizacji podstaw dla udoskonalonego działania na podobnych danych w przyszłości oraz wyrażania tych podstaw w zrozumiałej i symbolicznej postaci" (Miche, 1991, za: Stefanowski, 2009, s. 5). Według Danko Nikolica „uczenie maszynowe jest nauką o systemach i programach, które dokonują działań nie będąc wcześniej bezpośrednio zaprogramowane w tym" (Digital Poland, 2018, s. 140). Może przebiegać ono w dwóch formach: nadzorowanej przez człowieka oraz bez nadzoru, z wykorzystaniem uczenia głębokiego i sztucznej sieci neuronów (s. 141).

Maszyna wykorzystująca mechanizm sieci neuronowych i maszyna samoucząca się tym różni się od maszyny obliczeniowej, że wymaga działania człowieka tylko na etapie jej powstawania, a zakres jej użyteczności nie zależy wyłącznie od wstępnej formy, lecz poszerza się wraz z dostępem do danych i doświadczeń. To oznacza, że nie wymaga ona od twórcy przewidywania i programowania każdego kroku (Brzostek, 2016), tym samym ogranicza do minimum dyskryminujące cechy Beemzetów. Jej wzrost można zatem porównać do rozwoju dziecka, które otrzymuje określone wyposażenie genetyczne, jednak nie jest ono determinujące dla samego kierunku rozwoju.

Algorytmy samouczące przyjmują różne formy. Jedną z prostszych jest wirtualny asystent, który staje się powoli częścią naszego życia. Firma Gartner podaje, że do roku 2020 za $40 \%$ działań mobilnych będą odpowiedzialni wirtualni asystenci, a prognozy pokazują, że w roku 2018 ludzie mieli zainstalować w swoich domach ponad 2750 milionów tych urządzeń (Deloitte, 2019). Natomiast bardziej skomplikowaną formę przyjmują boty. Pierwszy z nich ELIZA, powstał 53 lata temu i potrafił budować relację z człowiekiem. Jego funkcjonowanie przypominało pracę terapeuty, zresztą w opinii rozmówców

czych i sposobu myślenia przypomina człowieka. AGI może wykonywać każde intelektualne zadanie, które może wykonać również człowiek" (Digital Poland, 2018, s. 139). 
- budzącego zaufanie. Dziś „osobowość” botów jest o wiele bardziej rozbudowana, a interakcja $\mathrm{z}$ nimi ma wzbudzać również ciekawość i zaangażowanie (Przegalińska, 2016). Przykładowo humanoidalny bot, który ma postać 7-letniego chłopca Shibuya Mirai, stworzony przez firmę Microsoft, od roku 2017 jest oficjalnym mieszkańcem Tokio i usprawnia komunikację urzędników z obywatelami miasta (Cuthbertson, 2017). „Dzisiejsze roboty to już nie urządzenia, które można wyłączyć z kontaktu i schować do szafy, to ‘żyjące’ istoty, prawdziwy Robo Sapiens" (Koczy, 2014, s. 77).

Tym, co absorbuje świat nauki jest próba osiągnięcia wpływu na kierunek procesu samouczenia maszyn (Hutson, 2018). Dotychczasowe próby użycia AI wyraźnie pokazują nam, że proces ten jest bardzo delikatny. Jednym z przykładów jest historia chatbota Tay, stworzonego przez firmę Microsoft, który po 24 godzinach w cyfrowym świecie stał się prawdziwym uosobieniem rasizmu, a jego ewolucja podążała w kierunku, który wzbudził zaniepokojenie jego twórców do tego stopnia, iż po 16 godzinach od uruchomienia postanowili go wyłączyć (Reese, 2016).

Próbę zarządzania uczeniem maszynowym podjęła w 2015 roku firma Google DeepMind, której poprzedni produkt AlphaGo pokonał w Go najlepszego na świecie gracza-człowieka. Twórcy przeprowadzili eksperyment $\mathrm{z}$ wykorzystaniem technik behawioralnych w uczeniu maszynowym. Stworzyli duplikat wcześniejszego programu o nazwie AlphaGo Zero, który sam został swoim nauczycielem. W ten sposób wprowadzili klasyczny system nagród $\mathrm{i}$ kar, poszerzony o wzmocnienia wynikające $\mathrm{z}$ pokonania $\mathrm{w}$ rozgrywce samego siebie. W każdym rozegranym ze sobą pojedynku sieć ulegała zmianie, ucząc się przewidywania kolejnych ruchów. Dzięki temu AlphaGo Zero nauczył się grać w Go bez wiedzy o grze, instrukcji i udziału ludzi. Skomplikowana forma uczenia oparta o sieci neuronowe rozwinęła umiejętności programu w bardzo szybkim tempie. AlphaGo Zero w starciu ze swoim poprzednikiem osiągnął wynik 100:o, zostając po 4 dniach nauki najlepszym graczem. Jednak tym, co najbardziej obrazuje korzyści z samouczenia się maszyn jest fakt, że maszyna w trakcie rozgrywki sięgała po rozwiązania, jakich nigdy wcześniej jeszcze nie widziano w grach między ludźmi, stając się tym samym twórcą nowej wiedzy i rozwiązań. W ten sposób ludzka wiedza i umiejętności przestały mieć dla niej znaczenie (Silver, 2017).

\section{Pedagogizacja maszyn}

Michał Klichowski pisał o „zmierzchu edukacji”, który wynika z faktu, że „technika jest (i już zawsze będzie!) efektywniejsza od edukacji” (2014, s. 162). Przytoczone argumenty wyraźnie pokazują, że nowoczesna technologia bez 
edukacji nie ma szansy rozwijać się w sposób, na jakim nam zależy. AGI stanowi sama w sobie jedynie pewną potencjalność. Bez zaplanowanego oddziaływania pedagogicznego kierunek jej rozwoju pozostaje pod znakiem zapytania. Według Aleksandry Przegalińskiej-Skierkowskiej „powinniśmy już teraz zastanawiać się, jaki może mieć wpływ przyszłe uspołecznienie botów na naszą z nimi koegzystencję” (2016, s. 13). Pytanie „o to, czy możliwa jest taka edukacja, która nie miałaby za zadanie wspierania rozwoju jedynie ludzkich aktorów sieci" (Chutorański, 2016, s. 257), trafnie oddaje znaczenie nauk pedagogicznych dla rozwoju nowych technologii. „Edukacja nie jest wyłącznie sprawą ludzi, a pedagogika stoi wobec wyzwania teoretycznej perspektywy, programów badań i polityki edukacyjnej ujmującej jej nie-ludzkich aktorów" (Chutorański, 2019, s. 9).

\section{Pedagogika rzeczy a sztuczna inteligencja}

Chutorański powiedział, że kształt materialności nie może stanowić tylko "mglistego tła ludzkich działań" (2019, s. 9). Technologia ma istotny wpływ na wszystkie obszary życia człowieka w takim samym stopniu, jak ten ma wpływ na technologię. Determinuje to ważne pytania o zbiorowość złożoną z ludzkich i nie-ludzkich aktorów. Szczególnie wyraźna jest potrzeba nowego odczytania „tradycyjnego podziału na aktywne podmioty i poddane ich woli pasywne przedmioty" (Chutorański, 2017, s. 152). Przywołując w tym miejscu kartezjańskie „Myślę, więc jestem”, warto zastanowić się, na ile w kulturze, która według Michela Foucaulta opiera się na zależności wiedzy i władzy (2006), zarządzający i wytwarzający informacje "pozaludzcy aktorzy” (Chutorański i Makowska, 2019, s. 12) mogą nadal być postrzegani przedmiotowo. $\mathrm{Na}$ ile jesteśmy w stanie zaakceptować, że wiedza przestaje być wytworem jedynie człowieka, a prezentowany przez AI sposób interpretowania świata może okazać się odmienny od ludzkiego, ale na równi właściwy? Pytanie to może zająć ważne miejsce w posthumanistycznej koncepcji pedagogiki rzeczy. Koncepcji, która jest

Próbą nazwania tych wysiłków badawczych, które skupiają się na rozumieniu zarówno znaczeń nadawanych rzeczom w procesach edukacyjnych, jak i opisowi związków ludzi oraz rzeczy, a także rekonstrukcji dynamicznych relacji między ludzkimi i pozaludzkimi aktorami procesów edukacyjnych i kulturowych; edukacyjnych relacji między tym, co ludzkie i pozaludzkie (Chutorański i Makowska, 2019, s. 12).

Markus Lipowicz pyta, wyrażając zaniepokojenie o transhumanistyczną wizję przyszłości: 
Czy jesteśmy gotowi na taki rozwój wydarzeń? Czy będziemy z perspektywy pedagogiczno-antropologicznej skłonni przywitać nowego, technologicznego (nad)człowieka - anthropos 2.0 - gestem otwartości? (2016, s. 78).

W mojej opinii proces ten jest nieuchronny i w dużej mierze już następuje, a jego przebieg będzie możliwy do uchwycenia dopiero z pewnej perspektywy czasowej. Natomiast zadane przez Lipowicza pytanie oddaje sedno założeń teorii aktora-sieci, iż najważniejsze w zbiorowości są sieci materialno-semiotyczne pomiędzy akantami (Latour, 2010) i to od nich zależy nasza przyszłość. Dziś z pewnością możemy przewidywać, że

jeśli powstaną w pełni inteligentne maszyny, będące w zasadzie już wtedy określonymi istotami (...) ich odmienność i swoistość własnego świata będzie tak wielka, iż będą stanowiły niezależne indywidua rządzące się specyficznymi regułami i kierujące własnymi celami (Koczy, 2014, s. 87).

Taki sposób postrzegania obecności AI zgodny jest z propozycją pedagogiki rzeczy, w ramach której - m.in. Chutorański czy Makowska - postulują porzucenie antropocentryzmu i uprzywilejowanego miejsca człowieka na rzecz symetrycznej relacji z rzeczami, a wszystko to w myśl uznania prawa do obecności każdej rzeczy (Chutorański, 2019).

„Rzeczy istnieją $\mathrm{w}$ świecie niezależnie od nas i naszego ich postrzegania, więcej, istnieją niezależnie od innych rzeczy" (s. 23). Tak ujęta posthumanistyczna ontologia przedmiotów w pedagogice rzeczy może stanowić zarówno kategorię uwrażliwiającą na znaczenie rozumienia pozycji AGI w świecie, jak i kategorię wyjaśniającą. Poszukując bowiem empirycznych narzędzi służących badaniu - i dalszej części kształtowaniu świata maszyn - nie sposób odmówić trafności proponowanej przez pedagogikę rzeczy posthumanistycznej perspektywy badawczej, która koresponduje z jednym z podstawowych założeń teorii ANT, iż działanie bytów pozaludzkich powinno być analizowane na równi z ludzkimi. Trafność tego postulatu - w mojej opinii - wynika głównie z tego, iż tradycyjne procedury edukacyjne mogą okazać się zupełnie nieskuteczne w stosunku do maszyny. Chociaż sieci neuronowe swą strukturą przypominają budowę ludzkiego mózgu, a sama AGI mocno wzorowana jest na człowieku, to sama odrębność w konstruowaniu wiedzy przez AGI determinuje konieczność przekroczenia humanistycznej wizji świata.

Pedagogika rzeczy stanowi ciekawą i ubogacającą perspektywę, akcentuje ona bowiem wzajemny wpływ pomiędzy ludzkimi i (nie)ludzkimi uczestnikami zbiorowości, i ta perspektywa wydaje się być najodpowiedniejszym punktem wyjścia dla prób wyjaśniania i kształtowania „relacji” człowieka z maszyną. 


\section{Pedagogika sztucznej inteligencji}

Powstanie pedagogiki sztucznej inteligencji (AIP) jest odpowiedzią na potrzebę wzbogacenia metod uczenia się maszyn. Istnieje kilka powodów, dla których potrzebę tę należy zacząć realizować już dziś, a jednym z nich jest fakt, iż według naukowców zajmujących się sztuczną inteligencją istnieją już wystarczająco zaawansowani „uczniowie” (Bieger, 2016). Czyli tacy, których rozwój może być kształtowany również w obszarze kompetencji społecznych. Nowa pedagogiczna teoria wzbogacająca uczenie się maszyn jest ważna z dwóch powodów.

Pierwszy koresponduje z postulatem Makowskiej i Chutorańskiego, którzy podkreślają fakt, iż „edukacja stanowi kombinację ludzi i nie-ludzkiej materialności mającej na celu "wspieranie ludzkiego rozwoju»" (Makowska, Chutorański, 2016, za: Lipowicz, 2016, s. 75). Z tego punktu widzenia pedagogika sztucznej inteligencji może stanowić jeden z ważniejszych, osadzonych wbrew pozorom $\mathrm{w}$ humanistyce, pośrednich czynników mających wpływ na rozwój człowieka żyjącego w nie(tylko)ludzkich zbiorowościach. Udział pedagogów w procesie rozwoju inteligentnych maszyn pozwoli być może na kształtowanie tych pozaludzkich aktorów sieci w sposób zgodny $\mathrm{z}$ akcentowanym przez humanistykę światem wartości. Bowiem nie da się zaprzeczyć, że wiek zwany czwartą rewolucją przemysłową, to czas, w którym według Klausa Schwaba świat „zmierza do zjednoczenia zasobów materialnych i cyfrowych" (2018, s. 11-12). Zjednoczenie to, jak przewidują futuryści, zmieni w fundamentalny sposób model życia człowieka, bowiem my „kształtujemy narzędzia, a potem one kształtują nas" (McLuhan, 2004, s. 17).

W tym miejscu należałoby zadać fundamentalne pytanie, czy w ogóle można mówić o wychowaniu sztucznej inteligencji? A jeżeli tak, to w jaki sposób i ku czemu? O ile bowiem, jak postuluje Władysław Duch, nie da się regulować samej sztucznej inteligencji, a jedynie systemy, które się nią posługują (2019), o tyle jednak propozycja zespołu tworzącego podwaliny koncepcji AP wyraźnie pokazuje, iż wpływ na proces samouczenia się maszyn może dotyczyć wielu różnych pośrednich i bezpośrednich płaszczyzn. Nie bez znaczenia pozostaje również pytanie, czy maszyny mogą być moralne? Potrzeba rozwijania badań nad rozwojem czynników moralnych, etyką maszyn czy sztuczną moralnością jest jednym z podstawowych zagadnień postulowanych przez środowisko naukowe, jednocześnie budząc wiele wątpliwości co do możliwości wpływu człowieka na rozwój raz skonstruowanego algorytmu samouczącego (Wallach, Allen, 2009). Pytanie to jest o tyle trudne, iż wyniki dotychczasowych eksperymentów związanych z zaprojektowaną moralną maszyną, w tym przypadku autonomicznym samochodem, realizowanych 
w Media Lab na MIT przez Jeana-Françoisa Bonnefona, Azima Shariffa oraz Iyada Rahwana wyraźnie pokazują, że u podstaw problemu moralności maszyn nie leżą kwestie techniczne związane z samym programowaniem algorytmu podejmującego etyczne decyzje (czyli zgodne $\mathrm{z}$ architekturą algorytmu), lecz ludzka trudność w określaniu przejrzystych, w tym przypadku często binarnych, zasad rządzących pożądaną moralnością (2016).

Drugi czynnik związany jest $\mathrm{z}$ rozwojem nowych technologii. W tym kontekście AP może usprawnić wykorzystywanie sztucznej inteligencji w nieprzewidywalnych warunkach. Jednocześnie stanowiąc rozwiązanie problemu wynikającego z coraz niższej wydajności programistów oraz ograniczeń tradycyjnej inżynierii konstrukcyjnej na coraz wyższych stopniach zaawansowania nowych technologii, np. poprzez usprawnienie samej komunikacji pomiędzy inteligentną maszyną a programistami, ponieważ pewne jest, iż swoistość używanych przez sztuczną inteligencję nośników wiedzy będzie wzrastać (Bieger, 2016).

Po trzecie, zgodnie z teorią konstruktywizmu, AGI bardziej potrzebuje dostępu do źródeł i doświadczeń, z których może wnioskować, niż dużej ilości danych wtłaczanych za pomocą programowania (Bieger, 2016). To właśnie dane i treści, do jakich samouczący się algorytm ma dostęp mają kluczowy wpływ na zmianę parametryzacji samego algorytmu i w konsekwencji zasad jego funkcjonowania. Algorytm taki wnioskuje - jak człowiek - ale to od nas zależy, jakie doświadczenia, przekonania, czy wiedza zostaną mu w toku edukacji dostarczone.

Teoria nauczania sztucznej inteligencji wymaga wielu lat intensywnej pracy, aby udzielić odpowiedzi na podstawowe pytania o zakres jej stosowalności, ramy koncepcyjne, definicje i metody (Bieger, 2016). Jeden z pierwszych kroków wykonał zespół Jordi Biegera, Kristinna R. Thórissona i Basa R. Steunebrinka. W artykule Pedagogiczny Pentagon zaproponowali wstępne ramy koncepcyjne pedagogiki sztucznej inteligencji, dzięki którym dalsza praca badawcza może być bardziej usystematyzowana. Ich zdaniem prace w obrębie nowego nurtu pedagogiki powinny koncentrować się wokół pięciu pojęć: uczniowie, środowisko zadaniowe, testowanie służące poznawaniu ucznia i jego postępów, szkolenie i nauczanie dotyczące ogólnej strategii, metod i narzędzi w AP. Twórcy nadmieniają, iż możliwa jest praca w obrębie jednego z pięciu wymienionych aspektów, jednak należy pamiętać, iż są one wzajemnie silnie powiązane (2017). W dalszym ciągu otwarte pozostają pytania nie tylko o to, jaki byłby najlepszy sposób nauczania, ale też w jaki sposób oceniać postępy ucznia, a także pracę nauczyciela. Jakie stosować metody nauczania i w którym środowisku zadaniowym będą miały one najlepsze zastosowanie (Bieger, 2016). 
Ponieważ AIP dedykowana jest nie tylko sztucznej inteligencji, lecz przede wszystkim człowiekowi, który chce ostatecznie mieć wpływ na proces rozwoju maszyn samouczących się, istotne wydaje się rozważenie jeszcze kilku kwestii. Według mnie szczególnie warte uwagi jest rozważenie podmiotowości sztucznej inteligencji, określenia ram definicyjnych jej rozwoju oraz ograniczeń wynikających z nakładanej na nią funkcji „maszyny użytecznej człowiekowi" i w swoim rozwoju zależnej od jego planów.

Uważam, że rolą pedagogów jest zaakcentowanie w przedstawionej koncepcji pedagogiki sztucznej inteligencji znaczenia jej wariantu humanistycznego. W mojej opinii takiego, który byłby zorientowany na budowanie wpływu na maszyny samouczące, który uwzględniałby świat wartości przypisany człowiekowi. Niestety, dotychczas przedstawiona koncepcja pedagogiki sztucznej inteligencji traktuje rolę pedagogów i wkład tej dyscypliny w rozwój nowych technologii w sposób jedynie techniczny, koncentrując się na samej teorii organizowania uczenia. Pomija świat wartości i wątpliwości związanych z rozwojem sztucznej inteligencji. Nie pyta w dalszej kolejności o samo człowieczeństwo we współczesnym świecie, o miejsce maszyn w świecie człowieka, o rolę nauczyciela w procesie samouczenia się maszyn, o znaczenie jego relacji z AI, o konsekwencje tej relacji i co najważniejsze o kierunek wychowania AI. Znaczenie humanistycznego wymiaru nauki o sztucznej inteligencji obrazuje poniższa wypowiedź prof. Tadeusza Gadacza:

Fizyk potrafi rozbić atom, wyzwolić ogromną energię drzemiącą w malutkich cząstkach. Ale to humanista stawia pytanie, do czego użyjemy tej energii - czy będziemy budować elektrownie jądrowe czy bomby jądrowe. Ich użyteczność dla przyszłości ludzkości jest skrajnie różna, ale różnica ta jest kluczowa (...). Pozbawienie świata i człowieka humanistyki skaże nas na jakąś jednowymiarowość - świat bez wartości nie może istnieć. Bez samopoznania i kultury nie można być także lepszym człowiekiem. Niebudowanie dobrych domów oznacza budowanie złych domów (2009).

\section{Wnioski}

Ponieważ "charakterystyczną cechą zachodzących zmian jest niekontrolowane przyspieszenie rewolucji technologicznej" (Siemieniecki, 2013, s. 23), wyzwanie stojące przed pedagogami nie dotyczy już rozwikłania kwestii gotowości do wspomagania tego procesu, lecz powinno przyjąć formę poszukiwania odpowiedzi na pytanie, w jaki sposób go wspierać i jakich form pedagogiki AI nie akceptujemy. Fakt ten podkreśla uwrażliwiający postulat Lipowicza o możliwym negatywnym wpływie urzeczywistnienia transhumanistycznej wizji przyszłości (w tym przypadku związanej z biotechnolo- 
gicznym udoskonaleniem człowieka), której konsekwencje mogą „anonsować kres obrazu człowieka jako osoby zdolnej do świadomego i podmiotowego samokształcenia" (2016, s. 88). Pedagogika sztucznej inteligencji, choć wyrasta $z$ transhumanistycznej wizji przyszłości, może, a w mojej opinii powinna, stać na straży humanistycznego postulatu o kształtowaniu środowiska, w tym maszyn, w sposób, który wspiera prawidłowy rozwój człowieka.

W Europie pojawiła się inicjatywa - ze strony wielu środowisk akademickich - stworzenia międzynarodowej jednostki naukowej wspierającej rozwój oraz inwestycje w obszarze sztucznej inteligencji ELLIS (Sample, 2018). Dla polskich naukowców perspektywa ta wydaje się odległa, choćby z racji tego, iż sama e-edukacja znajduje się w naszym kraju jeszcze w okresie prenatalnym (Muchacki, 2014, s. 37). Już dziś jednak można zaryzykować stwierdzenie, iż bez pomocy sztucznej inteligencji niemożliwa stanie się umiejętność korzystania z rozwiązań technologicznych zastosowanych we współczesnym świecie. Stanie się ona bowiem w przyszłości twórcą i przewodnikiem po świecie, do którego przynależy zarówno robot, jak i człowiek.

Na gruncie przytoczonych rozważań wyłania się podstawowe pytanie, czy Pedagogika Sztucznej Inteligencji powinna pretendować do miana nowego nurtu w pedagogice, czy może stanowić ubogacającą perspektywę dla istniejącej już interdyscyplinarnej nauki zajmującej się rozwojem AI, wzbogacając ją o istniejące już w pedagogice zaplecze sprawdzonych narzędzi i metod? W jaki sposób dostosować narzędzia stworzone dla człowieka do potrzeb edukacyjnych AI, jak mierzyć efektywność? Jak kształcić pedagogów zajmujących się kształceniem AI? I kto ostatecznie jest przedmiotem oddziaływań pedagogiki AI, maszyna czy człowiek, który z niej korzysta?

Powyższy tekst pozwolę sobie zakończyć cytatem, który w dużej mierze dotyka materii zwanej przez Lipowicza „irytującą wizją przyszłości” (2016, s. 75). Nasze wizje przyszłości mogą się bardzo od siebie różnić, mogą wzbudzać w nas odmienne emocje i uruchamiać inne pragnienia, nie możemy jednak o nich nie rozmawiać (Kozielski, Olsztyński, Soroczyński, 2018, s. 141).

\section{BIBLIOGRAFIA}

Bieger, J. (2016). Artificial Pedagogy: A Proposal. HLAI Doctoral Consortium. Pozyskano z: http://jordi.cyberbyte.nl/files/bieger_hlai_proposal_presentation.pdf [data dostępu: 01.06.2019].

Bieger, J., Thórisson, K.R., Steunebrink, B.R. (2017). The Pedagogical Pentagon: A Conceptual Framework for Artificial Pedagogy. 212-222. 10.1007/978-3-319-63703-7_20. Pozyskano z: https://www.researchgate.net/publication/318434649_The_Pedagogical_Pentagon_A_ Conceptual_Framework_for_Artificial_Pedagogy [data dostępu: 07.06.2019].

Bednarek, J. (red.) (2014). Człowiek w obliczu szans cyberprzestrzeni i świata wirtualnego. Warszawa: Engram. 
Bonnefon, J. -F., Shariff, A., Rahwan, I. (2016). The social dilemma of autonomous vehicles. Science, 352. Pozyskano z: https://arxiv.org/pdf/1510.03346 [data dostępu: 14.09.2019].

Brzostek, M. (2016). Rozważania o uczeniu się maszyn (machine learning) i sztucznej inteligencji. Pozyskano z: https://pclab.pl/art71255-3.html [data dostępu: 04.04.2019].

Czopek, J. (2017). Czy w edukacji jest miejsce na Big Data, Bilans szans i zagrożeń. Zeszyty Naukowe Wyższej Szkoły Humanitas. Pedagogika, 14, 83-90.

Chutorański, M. (2016). Nie(tylko)ludzka pedagogika. W: K. Węc, A. Wierciński (red.), Ryzyko jako warunek rozwoju. Transformatywne aspekty edukacji. Toruń: Wydawnictwo Adam Marszałek.

Chutorański, M., Makowska, A. (2019). Czy(m) jest pedagogika rzeczy? Wprowadzenie. W: M. Chutorański, A. Makowska (red.), Rzeczy, kultura, edukacja. Szczecin: Wydawnictwo Naukowe Uniwersytetu Szczecińskiego.

Chutorańki, M., Makowska, A. (2017). Sprawozdanie z I Ogólnopolskiej Interdyscyplinarnej Konferencji Naukowej: Pedagogika rzeczy. Rzeczy w procesach edukacyjnych i ich kontekstach. Szczecin, 23-24 maja 2017 r., Parezja, 2 (8).

Chutorański, M. (2019). Posthumanizm(y) i pedagogika. W: M. Chutorański, A. Makowska (red.), Rzeczy, kultura, edukacja. Szczecin: Wydawnictwo Naukowe Uniwersytetu Szczecińskiego.

Cuthbertson, A. (2019). Tokyo: Artificial intelligence „boy” Shibuya Mirai becomes wordl's first AI bot to be granted residency. nEWSWEEK. Pozyskano z: https://www.newsweek. com/tokyo-residency-artificial-intelligence-boy-shibuya-mirai-702382 [data dostępu: 01.06.2019].

Digital Poland (2018). Przegląd Strategii Rozwoju Sztucznej Inteligencji na Świecie. Warszawa: Fundacja Digital Poland.

Duch, W. (2019). Nadchodzi era Homo Sapiens Digital. Rozmowa z prof. Włodzisławem Duchem o sztucznej inteligencji. Pozyskano z: https:// https://plus.expressbydgoski.pl/nad chodzi-era-homo-sapiens-digital-rozmowa-z-prof-wlodzislawem-duchem-o-sztucznejinteligencji/ar/13965220 [data dostępu: 05.07.2019].

Foucault, M. (2006). Słowa i rzeczy. Archeologia nauk humanistycznych, Gdańsk: Słowo/ Obraz/Terytoria.

Gajek, M. (2019). Algorytm estoński czy chiński. Newsweek, 24, 59.

Gadacz, T. (2009). Czy humanistyka jest jeszcze potrzebna, wykład w ramach Festiwalu Nauki. Pozyskano z: https://www.polskieradio.pl/23/266/Artykul/180147,Czy-humanistyka-jestjeszcze-potrzebna [data dostępu: 05.07.2019].

Hutson, M. (2018). How researchers are teaching AI to learn like a child. Science. 10.1126/science.aau2576. Pozyskano z: https://www.sciencemag.org/news/2018/05/how-researchers-areteaching-ai-learn-child [data dostępu: 01.06.2019].

Ile waży praca (2017). Forbes. Pozyskano z: https://www.forbes.pl/technologie/jak-wiele-da nych-produkujemy-kazdego-dnia/4mn4w69 [data dostępu: 04.06.2019].

Klichowski, M. (2014). Narodziny cyborgizacji. Poznań: Wydawnictwo Naukowe UAM.

Kozielski, R., Olsztyński, R., Soroczyński, T. (2018). Internet Ludzi, organizacja jutra. Warszawa: Wydawnictwo Nieoczywiste.

Koczy, S. (2014). Edukacyjne możliwości stosowania robotów humanoidalnych. W: J. Bednarek (red.), Człowiek w obliczu szans cyberprzestrzeni i świata wirtualnego. Warszawa: Engram.

Latour, B. (2010). Splatajac na nowo to, co społeczne. Wprowadzenie do teorii aktora-sieci. Kraków: Towarzystwo Autorów i Wydawców Prac Naukowych „Universitas”.

Lipowicz, L. (2016). Anthropos 2.0 - od pedagogiki rzeczy do urzeczowionego człowieka? Parezja, 2 (6).

Lipowicz, M. (2019). Ulepszenie człowieka poprzez jego urzeczowienie? Pedagogiczna antropologia wobec wyzwań liberalnej eugeniki i transhumanizmu. W: M. Chutorański, 
A. Makowska (red.), Rzeczy, kultura, edukacja. Szczecin: Wydawnictwo Naukowe Uniwersytetu Szczecińskiego.

McLuhan, M. (2004). Zrozumieć media. Przedłużenia człowieka. Warszawa: Wydawnictwo Naukowo-Techniczne.

Muchacki, M. (2014). Cywilizacja informatyczna i Internet. Kraków: Oficyna Wydawnictwa Impuls.

Menzel, P., D’Aluisio, F. (2002). Robo Sapiens. Wydawnictwo G+J .

Müller, V.C., Bostrom, N. (2016). Future Progress in Artificial Intelligence: A Survey of Expert Opinion. Pozyskano z: http://www.nickbostrom.com/papers/survey.pdf [data dostępu: 10.06.2019].

Najszybszy komputer świata, http://przystaneknauka.us.edu.pl/artykul/najszybszy-komputerna-swiecie [data dostępu: 04.06.2019].

O’Neil, C. (2017). Broń matematycznej zagłady. Warszawa: Wydawnictwo Naukowe PWN.

Przegalińska-Skierkowska, A. (2016). Konflikt generacyjny wśród botów. W: V. Kuś (red.), Live Bot. Monografia (s. 10-14). Enaukowiec. Pozyskano z: https://www.academia. edu/30983681/Konflikt_generacyjny_miedzy_Eliza_Cleverbotem_i_Tay_w_monografia_ pod_redakcj\%C4\%85_Violki_Ku\%C5\%9B [data dostępu: 05.06.2019].

Przegląd Strategii Rozwoju Sztucznej Inteligencji na Świecie (2018). Warszawa: Fundacja Digital Poland.

Raport: „Global TMT Predictions 2019, Prognozy dla sektora technologii, mediów i telekomunikacji. Pozyskane z: https://www2.deloitte.com/pl/pl/pages/technology-media-and-tele communications/articles/tmt-predictions-2019.html [data dostępu: 11.06.2019].

Reese, H. (2016). Why Microsoft's 'Tay' AI bot went wrong. Tech Republic.com. Pozyskano z: https://www.techrepublic.com/article/why-microsofts-tay-ai-bot-went-wrong.

Rosenfield, A. (2018). Summit by the numbers. IBM Research Blog. https://www.ibm.com/ blogs/research/2018/o6/summit/ [data dostępu: 01.06.2019].

Sample, I. (2018). Scientists plan huge European AI hub to compete with US. The Guardian. Pozyskano z: https://www.theguardian.com/science/2018/apr/23/scientists-plan-huge-european-ai-hub-to-compete-with-us [data dostępu: 08.06.2019].

Siemieniecki, B. (2013). Pedagogika kognitywistyczna. Studium teoretyczne. Kraków: Oficyna Wydawnicza Impuls.

Stefanowski, J. (2009). Wykład „Maszynowe uczenie się”. Instytut Informatyki Politechnika Poznańska. Pozyskano z: http://www.cs.put.poznan.pl/jstefanowski/ml/NEWML_ Wilastr.pdf [data dostępu: 14.09.2019].

Sztokfisz, B. (2018). Międzynarodowy wymiar współpracy w zakresie rozwoju sztucznej inteligencji. W: Przegląd Strategii Rozwoju Sztucznej Inteligencji na Świecie. Warszawa: Fundacja Digital Poland.

Silver, D., Schrittwieser, J., Simonyan, I., Antonoglou, I., Huang, A., Guez, A., Hubert, T., Baker, L., Lai, M., Bolton, A., Chen, Y., Lillicrap, T., Hui, F., Sifre, L., Van den Driessche, G., Graepel, T., Hassabis, D. (2017). Mastering the game of Go without human knowledge. Nature, 505, 354-359.

Schwab, K. (2018). Czwarta rewolucja przemysłowa. Przeł. A.D. Kamińska. Warszawa: Wydawnictwo Studio EMKA.

Selwyn, N. (2015). Data entry: towards the critical study of digital data and education. Learning, Media and Technology, 40/1.

Szwed, R. (red.) (2003). Społeczeństwo wirtualne: społeczeństwo informacyjne. Lublin: Katolicki Uniwersytet Lubelski.

Wallach, W., Allen, C. (2009). Moral Machines Teaching Robots Right from Wrong. Oxford University Press. 


\section{SUMMARY}

Machine Learning: a Challenge of Contemporary Pedagogy

The article discusses artificial intelligence pedagogy (AIP), focusing on its significance in the context of big data and machine learning. It presents the concept of pedagogy pentagon proposed by the team of J. Bieger, K.R. Thórisson and B.R. Steunebrink. It also refers to the proposal of five fundamental notions of the new teaching theory intro $\neg$ duced by the above team (students, task environment, testing aimed at getting to know students and their progress, training and teaching in the area of general strategy, AP methods and tools) as the starting point for discussions on the introduction of humanistic dimension to robotics or development of artificial intelligence technology. For that purpose, the article adopts the concept of pedagogy of things proposed by A. Makowska and M. Churotański, demonstrating its potential for the explanation and raising awareness for further development of artificial intelligence pedagogy.

KEYWORDS: artificial intelligence pedagogy (AIP), artificial pedagogy (AP), artificial intelligence (AI), pedagogy of things, pedagogy pentagon, machine learning $(\mathrm{ML})$ 